\title{
Between the Global and the Private: The Second World War and the Cold War in Two Novels by Lithuanian-Canadians
}

\begin{abstract}
This article offers an analysis of selected texts of Lithuanian-Canadian literature which concentrate on different perceptions of war. It explores the secret war of the 1940s led by the Lithuanian underground during the Second World War, as presented in Antanas Sileika's Underground (2011), and the Cold War period analyzed by Irene Guilford in The Embrace (1999). Since these texts present certain marginalized, multicultural perspectives on conflicts and highlight the tensions in locations situated outside Canada, it is the ethnic perspective which allows the authors to introduce their stories into the Canadian literary scene. The article also raises questions concerning the links between family members torn apart by conflicts as well as dilemmas regarding heroism and betrayal. Finally, the influence of global conflicts on personal choices and identities is examined.
\end{abstract}

Key words

Lithuanian-Canadian literature; Irene Guilford; Antanas Sileika; the Cold War; the Second World War; diasporic literature; multicultural literature; ethnic literature

\section{Introduction}

Canada has always been regarded as a peacekeeping nation. Simultaneously, it is also perceived as a haven for immigrants who are welcomed and embraced by the policy of multiculturalism. As a result, various immigrant and ethnic groups have settled down in Canada burdened with their experiences and histories of past wars, conflicts, and resentments. Therefore, ethnic literature quite often functions 
as an outlet for these past stories and memories of the conflicts witnessed or heard about at home as well as a confrontation with the perception of Canada seen traditionally as a "Peaceable Kingdom". This essay explores the secret war of the 1940s led by the Lithuanian underground during and after the Second World War, as presented in Antanas Sileika's Underground (2011), and the Cold War separation between Lithuania, then part of the Soviet Union, and Canada, which is explored by Irene Guilford in The Embrace (1999). Since these texts show certain marginalized, multicultural perspectives on conflicts and highlight the tensions in locations situated outside Canada, it is the ethnic perspective which allows the authors to introduce their stories into the Canadian literary scene. Despite the fact that the policy of multiculturalism was introduced to the Canadian debate in the 1970s and sanctioned formally in 1988, it is the 1990s in which "the voices of Canada's many ethnic minorities have begun to be heard" (Danyte 2003: 74). As Rūta Šlapkauskaite claims, texts by Sileika and Guilford "mediate their concerns for the ancestral culture in their narratives" (2008b: 68) ${ }^{1}$ and, as such, offer in-depth studies of the global conflicts which at the same time become the private, secret wars influencing the lives and identities of both Lithuanians and Lithuanian-Canadians.

\section{Historical Layers in Antanas Sileika's Underground}

In his texts, Antanas Sileika frequently investigates the issue of double belonging and hybridization in multicultural Canada. He has written several books devoted to various topics: Dinner at the End of the World (1994), Buying on Time (1997), Woman in Bronze (2004), and Underground (2011). The acclaimed Buying on Time, which is a collection of linked short stories describing the Lithuanian DPs in Canada, presents a more ironic perspective on Lithuanian immigration in Canada. On the other hand, Underground, is a serious, compelling story of the Lithuanian partisans who fought against the Soviets at the end of the Second World War and afterwards. ${ }^{2}$ Although the story is based on true accounts, such as Juozas Luksa's 1950 book Partizanai as well as various other documents and texts found in the archives and published after 1991, Sileika insists on its fictionality. Nevertheless, the Acknowledgement section leaves no doubts that Underground is an outcome of deep studies and research, and, as such, is an important voice in the discussion concerning the fights of the resistance movement in Lithuania as well as the Western approach to it. Above all, it is also a story concerning identity; what it means to be a Lithuanian in the 1940s Soviet Union and in the west of Europe and in Canada.

As a Lithuanian-Canadian who was born in Canada, Sileika is aware of the lack of knowledge about Lithuania and its history in the West. One of his tasks is to fill in the blank pages of Western consciousness and through telling children of immigrants, such as himself, the story, he also tries to capture the Lithuanian identity trapped between its great but painful history and its silencing for fifty 
years. Not only does Sileika bring to the discussion the ethical questions concerning the partisans' actions but he also almost physically excavates the stories of the secret war, forgotten and silenced by official history. The readership is obviously not limited to the first, second or third generation of immigrants. Since Sileika has been interested in rendering unofficial memory and history as well as fusing the global with the private for many years, Underground is, therefore, a sum of his views on writing history and bringing the topic of the marginalized past to wider audiences. Milda Danyte's analysis of Sileika's earlier novel, Woman in Bronze (2004), shows that the writer's fascinations circulate around showing "the unofficial memory that provides the historical intertexts" which is "plac[ed] at the heart of his narrative" (2007: 36). Moreover, Danyte accurately classifies Sileika's books as "post postmodern historical novels" (2007: 40). In her explanation of the term, she views the new type of historical novel as the one that fuses history with autobiography and rejects the traditional, national myths and heroes as well as postmodern, revisionist approach to the past. Indeed, in Underground, Sileika neither glorifies his main protagonist nor parodies him as an anti-hero. Moreover, with the post-1989 opening of Lithuanian archives, he is able to intertwine the biography of Juozas Luksa, the fictionalization of it, with the formerly unofficial history. I would then argue that it is not only Woman in Bronze but his latest artistic endeavor that falls into the category of post postmodern historical novels. The combination of the global conflict with its completely unknown to larger audiences local aspect with the private, that is personal life a partisan, proves innovative to the challenged genres of traditional historical novel and its postmodern rewriting. As a result of such conceptualizations of historical writing, Sileika introduces his Anglophone readers to the tangled history of Lithuania in the global perspective as well as through the individual choices of the main protagonist, Lukas.

The text opens with a quotation from Landscape and Memory by Simon Schama, which depicts Lithuania as landscape that "had seen war and terror, elation and desperation; death and resurrection; Lithuanian kings and Teutonic knights, partisans and Jews; Nazi Gestapo and Stalinist NKVD. It is a haunted land where greatcoat buttons from six generations of fallen soldiers can be discovered lying amidst the woodland ferns" (Schama as qtd. in Sileika 2011: epigraph page). From this point of departure, the book offers a sketch of Lithuanian history which goes back to medieval times but predominantly concentrates on the 1940s, presenting the end of WWII as a triumph in the West and a tragedy in the East where people had to bury their hopes of independence and freedom as "[w]hat followed was such a confusing war on that side of Europe! (...) On the Eastern side (...) the messy side, the war sputtered on in pockets for another decade, fought by partisans who came out of their secret bunkers by night" (3). The book focuses on the Lithuanian partisans (around 30,000 in total) who tried to fight the second Soviet occupation in 1944. Cut off from the knowledge of how the war was about to end in the West, the partisans hoped the British and Americans would help them prevent the Russians from occupying Lithuania and other Baltic countries. 
What they were very much aware of was the fact that "The Red Army brought Moscow-trained secret policemen into every occupied country, put local communists in control of national radio stations, and began dismantling (...) groups and (...) organizations. They arrested, murdered, and deported people whom they believed to be anti-Soviet, and they brutally enforced the policy of ethnic cleansing" (Applebaum 2013: 192-193). The disappointment resulting from the silence of the West made them bitter but also determined to fight until the end and perhaps in this way to awaken the conscience of the West:

It would have been better if the partisans had had wings to take them through the trackless sky. In that case they might have flown up to see that they were deep, deep in the Red-controlled zone, and there seemed to be no massing of American and West European troops coming to free them. The lack of troops would have been perplexing. The French and English had gone to war over Poland, so why did the Westerners let their young men die if not to save that country? Surely the next to be liberated after Poland should be Estonia, Latvia and Lithuania, which thought of themselves as part of the European family.

No one else did. The English had decided to give the three Baltic countries to the Soviets if they ever asked, but the Reds never bothered (...) And if the partisans could have looked into the future as well as into the distance, they would have seen fog descending over Eastern Europe, a haze of ignorance in which much of what the Reds said was believed in the West. (60)

As a result of the growing bitterness regarding the lack of the reaction from the West towards what happened to the Baltic States after WWII and the decimation of his comrade partisans, (who either lost their lives in the forest ambushes or were caught by the Cheka and were transported to Siberia), Lukas finally decided to go to the West in 1948 to look for help in person. Having been assured that his wife and fellow partisan, Elena, had died earlier, Lukas went to Sweden to organize the regular provisions for the Lithuanian underground who still tried to fight the Soviets. Frustrated by the procrastination of the Swedes, who wished to remain neutral, Lukas tries to engage the British or the Americans in the organization of help. However, it turns out that none of the Western countries is interested in acting out against Stalin openly and Lukas is involved in the fund raising actions prepared by the Lithuanian government-in-exile. For him this work mainly involves traveling around Germany and offering talks in various DP camps about the situation in the Baltic Soviet republics and the actions of the underground army.

This is the moment when, again, the global fuses with the private for Lukas, as in one of the camps he meets Monika, who is a Paris-based refugee herself, though quite affluent and mysterious. Lukas goes with her to France, where they get married and try to lead a normal life. What becomes clear is a conflict between two opposing alliances in the west: the one represented by the French- 
American line and the other belonging to the Swedes and the British. Involved in his life with Monika and the attempt to make himself understood in the socialist circles of post-war Paris, Lukas receives information about his Lithuanian wife, Elena, who is said to have survived the massacre and probably lives in Merkine, Lithuania. Though Lukas is aware that this might be a trap, he decides to go back to find Elena. Leaving a disoriented and disappointed Monika behind, he goes on a dangerous trip back to his country, now a Soviet republic where by that time the majority of the underground army was virtually wiped out. Unlike the previous sections where the stories of the partisans' numerous forest fights were meticulously depicted, the final parts present Lukas's story quite briefly. Having found Elena disfigured and living with their small son, Jonas, Lukas learns that she is certain his visit will either bring her death or deportation to Siberia.

The final part of the book leaps forward to 1989 in Canada where the reader is offered a coda to the story. Monika and Lukas's son, Luke, a high school teacher of French, receives a letter from his half-brother, Jonas Petronis from the town of Merkine in the now independent Lithuania who invites him to his homeland to learn the other part of the silenced story about his family. Since both of them did not know much about their pasts and their real parents, the story finishes when they meet and, despite feelings of awkwardness and ambivalence, are about to deliver the multilayered perspectives of their lives to each other.

\section{Haunting}

Despite the fact that the majority of the story in Sileika's book concentrates on Lukas and his activities as a partisan, and, as critics claim, the rest of the characters are only sketched (Baily Nurse 2011; Dundzilla 2012), Underground also displays some deeper, spectral layer. While the title obviously refers to the Lithuanian underground army, the word also has greater significance in the text. Alluded to in the motto to the book, underground refers to the many layers of dead men lying beneath the ground, buried in the course of the long history of Lithuania. It is by no means accidental that Sileika includes allusions to the atrocious invasions by the Teutonic knights, Swedes, Russians and also by Poles and the Soviets, that Lithuania has suffered throughout the centuries. The victims of all these bloody encounters lie in the deep ground, in the boggy landscape of Lithuania. This also concerns the history of Lithuanian Jews alluded to at the beginning and at the end of the book with the picture of Jewish Pine Forest near the town of Merkine. At first, Sileika offers a cue to the extermination of the Jews where only cemeteries and the forest tell the story. In the end, we learn, however, that the Kaunas Reservoir was made by the Soviet engineers in 1959 which flooded the site of commemoration of the Lithuanian Jewry. This spectral void, although not alluded to frequently in the story, haunts Lukas and his companions as they move across the country, hide in forests, cemeteries, and in scattered bunkers. 
The bog partisans are to follow in the footsteps of the previous generations of ghosts. Their wanderings among "les lieux de mémoire" (Nora 1989) are also to be silenced by the official history of the Soviet Lithuania for years to come. As Sileika says at the end of the book, "the stories that lay there [in the former Jewish Pine Forest] would be pried apart by the archeologists and geologists of the future" (305). The same refers to the stories of the Lithuanian underground army, the existence of which "remains largely repressed (...) in the East and in the West" (Bailey Nurse 2011). Marchand calls it the resurrection of history "erased from collective memory, of Lithuanian resistance against Stalin in postwar Europe" (2011). He also draws attention to the moment when "Lukas compares the partisans to Morlocks, the predatory, underground creatures in H.G. Wells' The Time Machine" and claims the term underground "is figurative, denoting a world of false identities, hiding places, a secret, invisible regime feeding off the aboveground society" (Marchand 2011).

Sileika's treatment of the spectrality and haunting which is experienced by the Lithuanian partisans in the bogs and forests of North-Eastern Europe can be linked with Derrida's conviction that "haunting is historical" especially in this region which is still "suffer[ing] from a certain evil" (Derrida 1994: 4). This evil is clearly denoted and denounced as WWII in general but Sileika decides to go further and refers to Eastern Europe, and Lithuania in particular, as the landscape which hides the cemetery of hundreds and thousands of nameless victims of wars, murders and pogroms, which took place there throughout the centuries. Numerous allusions to the archeology of memory and the memory of landscape bring Martin Pollack's concept of contaminated landscapes to mind. Pollack (2014) sees European landscapes, beautiful and comforting at first sight, as concealing the greatest cemeteries of the world; contaminated by the genocides of the $20^{\text {th }}$ century, these landscapes conceal the mass graves of dead soldiers and civilians. In his essay, Pollack questions what it means to live on such graves and whether the awareness of this fact changes the perception of these landscapes. Sileika also describes Lithuanian landscapes in this way. It is the forest, the glens, water, marshes and bogs which hide the layers of the dead. The opening quotation from Schama as well as Sileika's description of Lithuania as a place "somewhat quaint, yet so much more brutal than the West. (...) a place where generations were mown down as soon as they were tall enough to meet the scythe" (4) suggest the way the landscape haunts with its ambiguity. Moreover, the majority of the places of mass burials are not marked in any way. The truth is known to few people only and others, like peasants from nearby villages, who know some rumors are afraid to speak and do anything in order to commemorate the victims in any way. They try to live normally and to collect crops but for Sileika's partisans it becomes apparent that they all live in contaminated landscapes which become the sources of spectrality.

Following Gombrich's famous claim that "[t]he innocent eye is a myth" (1961: 298) and as a result "there is no innocent eye, no innocent ear" ([1960] 2000: 363), Schama (1995), and also Sileika in Underground, go further in their convic- 
tion that landscape is also never innocent. When the two brothers are reunited for a brief moment in Lithuania and are traveling together through the countryside, Sileika's narrator observes that

The countryside they drove through was made up primarily of pine forests that had been planted because the Soviet planners decided the sandy soil was too poor, and so the old farms had been liquidated, the fences dismantled, the houses bulldozed and the people resettled; geography was a slate that could be wiped clean, within limits (...) History, like geography, could be wiped away within reason as well, but like shards of pottery from ancient settlements it had a way of working up to the surface. A determined man or woman could piece some of it back together. (303)

The landscape hides the stories of the relocated people concealing the shards of memory and the bones of the dead. As such, landscape cannot be understood romantically as a soothing commodity but rather as one in which a discerning eye notices the layers of the buried. The Lithuanian landscape gives shelter to the partisans, as Sileika shows, but it also masks the truth of the past. Sileika calls for the surfacing of these stories and mentions the "archeologists of the future" (305) who will rediscover, at least partially, the places of anonymous mass burials.

Secondly, Sileika's novel uses the word "underground" in the context of the partisans' need to hide one's emotions in order to survive. Lukas, falls in love twice, yet has to abandon his wives and suppress his emotions. At the same time, he is a former student of literature, interested in poetry, and as such "he symbolizes the Lithuanian spirit" as "all Lithuanians are poets at heart" (Dundzila 2012). Simultaneously, this quotation refers back to the spectral haunting of this country left alone to defy the Reds and commemorate the romanticized past of Lithuanian heroes. During one of the conversations that Lukas has with his compatriot Lakstingala in 1946, it turns out that their understanding of emotions differs, as Lukas wants to talk openly about his beloved Elena, whereas Lakstingala prefers to remain silent about his wife and daughter:

'...I'm worried that you [Lukas]'re turning soft just as things get harder, just when you should be getting tougher. We're not the first ones to go into the woods, but we've lasted longer than anyone else. How are we going to survive unless we turn our hearts to stone?'

'I don't understand you.'

'It's not the Reds that worry me. It's your feelings. Those are what are going to get you killed.'

'How is it possible to live without feelings?'

'It's not, but you have to bury them in order to fight. If you become soft, you'll see the eyes of his mother in every Red you kill and you'll hesitate, and one day you'll die yourself. The only feelings you should have are a thirst for revenge and righteous anger.' (108) 
The question: "How are we going to survive unless we turn our hearts to stone?" refers to the Biblical call of the Holy Spirit who commands: “...do not harden your hearts" (Hebrew 3,8). The question of whether or not to hide emotions endangered by this secret war is yet another allusion to "the habit of Lithuanian men (...) burying their emotions" (Marchand 2011). The survival of the partisans seems to be of highest importance for the Lithuanian resistance but the irony and bitterness of the Biblical statement in this story consists in the fact that the West remained largely indifferent despite Lukas's passionate talks. As a result of the harsh operations of the Soviet Cheka against the Lithuanian underground army and scarce help from the West, the forces were dispersed and crushed during the first decade after WWII. It is only now that the stories are uncovered and rendered publicly in Lithuania where the "monuments to the Lithuanian partisans would join the monuments to the Red partisans and the Red Army" (305).

Furthermore, the Biblical question of survival may also refer to the moral ambiguity concerning the life and deeds of the partisans. The aforementioned concealment of emotions was also necessary in order to perform the brutal tasks of killing. As a result of that, another morally dubious question pertaining to partisans' heroism arises. Since Lukas's brother died in unknown circumstances and his body was never found, he became aware of the fact "he did not want to humanize his enemies, because those kind of feelings would make him weak in the work he must do" (74). On the other hand, however, Lukas asks himself how it is possible to love his parents, his beloved Elena, and finally his country without feelings and "yet it was strange that love of country should make one a killer, that love should lead to its opposite" (75). Undergound does not offer unequivocal answers to these dilemmas. Sileika offers no clues and leaves his readers with these serious problems. He insists on the fictionality of the book, seeing his task as a storyteller's rather than a morality preacher. He pinpoints the problematic areas in the history of Europe and diagnoses sensitive issues common to many generations and landscapes of Eastern and Central Europe.

Nevertheless, Sileika's novel is a tribute to the dedication of the Lithuanian underground fighting against the Soviet Union in the post-war period. However, it tries to grapple with the tangled question of Lithuanian identity from the Canadian perspective as well. In the final chapter, in which Luke Zolynas learns about his real father, Lukas, and his step-brother, Jonas Petronis in Lithuania, the last piece of the puzzle falls into place though the whole picture is far from being a consolation as:

Everyone is from somewhere, and memory was a mixed blessing. Look what happened to immigrant kids who didn't forget: they became enthusiastic ethnics, slightly comical figures in folk costumes, objects of derision. Or else they nurtured ancient hatreds and let them fester. Luke Zolynas loved Canada, in a way, not that he would ever put it in those words. But to him it never felt altogether like home. Sometimes he'd wondered if he'd landed in the wrong country. (302) 


\section{The Iron Curtain World(s) in Irene Guilford's The Embrace}

Irene Guilford is the author of one novel The Embrace which appeared in 1999 in Canada. Having graduated with a diploma in Mathematics and Computing, she has not produced an outstanding number of texts, although her literary output has been anthologized. She is also the editor of a volume devoted to Alistair MacLeod (Alistair MacLeod. Essays on His Works, 2001). The Embrace, however, turns out to be an insightful voice of a Lithuanian-Canadian concerning the impossible mutual relationships of two branches of a family torn apart by the Second World War and the Communist regime. It is interesting to see that Guilford in her novel does not offer easy reconciliations after the years of separation. The two branches of the same family, the Canadian one and the Lithuanian one under Soviet dominance, meet both in the Soviet Union and in Canada, but neither of these trips brings them closer to each other. Guilford's novel is divided into three parts: 'Lithuania, 1985,' 'Toronto, 1965' and 'Toronto, 1990.' In the first part of this compact book, the history, however, goes back to the political situation of Lithuania in 1944. It is during this year that the family split and it is also then when the future of the country was being decided on. 1985 is also the year in which the Canadian part of the family visits Lithuania. In the second part set in 1965, the main character, Aldona, undergoes a painful process of maturation and finding her identity as a Lithuanian-Canadian, while the final part, set in 1990, offers an attempt at the reconciliation of the two families. Lithuanian members of the family, freed from the Communist regime, come to Canada on a three month trip, which is supposed to restore their bonds in the free world.

\section{Search for identity}

During the first trip to Lithuania, Aldona's father, a Lithuanian who stayed in Canada after World War II, wants to show his daughter the beauty of his own country. They are, however, not fully aware of what kind of place the Soviet Union really is and what it has meant for their family members to live behind the Iron Curtain, this "unfathomable chasm, a divide between 'us' and 'them"' (Porter 2010: 1), for years. Her father's enthusiasm about the journey makes Aldona wonder from the beginning about the chances to get on well with their Lithuanian relatives. As a young person, married to a Canadian who has "pulled his name over [her], gratefully like a blanket" (13), this is also a journey of self-discovery. When asked about the absence of her Canadian husband, Aldona realizes that "This life of mine, the Lithuanian inside the Canadian, an arm hidden inside a sleeve, is something he doesn't understand" (14) and she has to deal with this realization alone. Throughout the first part of the story, Aldona and her father are involved in family discussions which only show the inability to comprehend the differences between the two worlds: the West and the Cold War East. As Aldona's narrative voice notes, "It's not that I'd expected weeping and embracing, 
a falling upon one another's necks, like in stories of long parted families that finally meet. Our separation has been too harsh, our Cold War silence too long and deep" (14). In spite of the problems in communication, both linguistic and emotional, or perhaps in order to compensate for his affluent life in Canada, Aldona's father visits a store for foreigners and uses his dollars to buy a whole range of things that are unavailable in the Lithuanian Soviet Republic at that time, from a car and a refrigerator to almost thirty pairs of sneakers, which is supposed to "free [him] from guilt" (27) of living in wealth. Under the close inspection of the Soviet secret police, as one might guess, the Lithuanian part of the family does not feel safe or comfortable during this visit. During this gift-giving ceremony (the Lithuanian family also tries to offer them as much as they can spare), what they miss is a true conversation, a relationship that might be somehow, at least partially, renewed. They discuss many significant things: "[w]e compare the cost of food and housing. We speak of salaries, of what it costs to live. At last, free of microphones, we speak of private things. But not things that matter." (33). Finally, one of the cousins offers a risky but illustrative description of the experience of living under the regime: "We are birds (...) Birds in a wooden cage" (33), which shows "a black hole that nothing can fill, and where nothing grows" (33). The families part again as Aldona and her father go back to Canada and the question of mutual understanding and reconciliation is left open and the rift between the two parties seems to be too deep to be overcome.

The other two sections of the novel refer to the past and the future. In the section devoted to 1965, Aldona becomes close pen friends with her Lithuanian relative, Daiva, whom, by the year 1985, she does not comprehend at all. She observes her father and grandparents, who demonstratively try to remain Lithuanian and to cling to their origins, speaking Lithuanian, preparing traditional dishes and pressing Aldona to follow in their footsteps. This chapter is full of identity questions and depicts the confusion of the fifteen-year old Aldona, who tries hard to create her own concept of being a hyphenated, hybrid Canadian:

I am different (...) I was born here. I am not you (...) I become a vessel, holding memories and dreams. Lithuania is a raw, silent hole. A bony hand holds the back of my head, pressing my face to a suffering so that I can't turn away. At Saturday school, we see pictures of soldiers holding families at bayonet point in farm kitchens I imagine my cousins thus (...) If they misbehave, they will be shipped to Siberia, or shot. (50)

Having experienced a regular Canadian childhood, and been pushed to attend a Lithuanian Saturday school and summer camps with other children of immigrants, Aldona comes to the following conclusion: "I don't fit in anywhere. Not among the Canadians where I was born. Not among the Lithuanians who came here. Not in Lithuania, a place I never left. I am invisible" (54). In the letters, she exchanges with Daiva, her Lithuanian cousin, Aldona finds cues of silent accusations of her own father's betrayal of Lithuania which is "a country stolen, 
a country lost" (79) inhabited by "a nation in mourning, a people in perpetual grief" (80).

This inability to define oneself is further deepened in the third section of the novel, when, in 1990, after the fall of Communism, the Lithuanian part of the family comes to Toronto. The idea of the American Dream, well-known to the Lithuanians, makes them decide to stay in Canada as illegal immigrants. This pushes Aldona, happily married to a Canadian and leading a comfortable life, to reformulate her ideas of family, which is definitely very difficult. This period of her life is full of guilt, identity questions and impotence in expressing her thoughts: "East and west, we sit, two islands of untalk, an ocean between" (106). This quotation summarizes the central tension in Guilford's novel: the question of whether there is a chance to find common ground for a discussion following such separate and distinct experiences. Is it possible at all to bridge almost half a century, or are such members of parted families 'two solitudes' (to use Hugh MacLennan's term in this context)? Having been determined by the lack of coherent conclusions, Guilford's novel offers the comprehension of a hybrid identity, of a discourse split in the immigrants' minds as well as in their children's. In the last passage of the novel, Aldona voices the post/memory she inherited, stating: "Home (...) is an imaginary place. A time before our births. A place we can never visit. A land where we wait, arms reaching towards the embrace" (150). She also acknowledges the spectral void of the past that continuously haunts her. These statements correspond to the opening paragraphs, coming from the author herself: "The ghost of my life in Lithuania exists, though I have never lived there. It lives in the minds of my grandparents and parents, my aunts, uncles and cousins. They see it, and I never having seen it, see it also. It is grey, like a shadow, and sad" (6). Even though the embrace is not fulfilled and the ghost remains sad, Guilford tries to express the danger of failure and, thus, addresses the pitfalls of multiculturalism. These shadows are the same ones that Janice Kulyk Keefer sees in Honey and Ashes, for example. Moreover, Guilford's personal experience in the form of the ghosts of the past haunting her encourages and fuels her novelistic writing. Like Eva Stachniak in Necessary Lies, Guilford inscribes her emotional identity and migrant experience into her fictional characters.

Rūta Šlapkauskaitė discusses The Embrace in two essays. One of these, a comparative study of Guilford and Sileika, shows how these writers' "creative consciousness may respond to the operations of Canada's multicultural conjuncture" (Šlapkauskaite 2008b: 73). In her article, Šlapkauskaitè explains the incomprehension of the two parts of the same family, claiming that "the Lithuanian characters in The Embrace operate as a metonymy of the oppressed nation: they are the native informants (...). As such, they are largely perceived as a single mass - inarticulate and indiscriminate" (Šlapkauskaitè 2008b: 70). In another text, Šlapkauskaite locates The Embrace within the postcolonial paradigm and claims that "Lithuania resurfaces as the spectral Other that haunts the protagonist's conscience with a promise of the lost arche, an authentic cultural voice" (Šlapkauskaite 2008a: 151, italics original). The book is seen by the Lithuanian 
critic as a pastiche "that replicates the ambiguities of multiculturalism and gratifies the expectations of a Western Reader" (Šlapkauskaite 2008a: 147). One may agree that the text by Guilford employs the division of the Canadian metropolitan center and the Soviet Other understood as a periphery. However, I would argue that the accusation that the novel is "a tourist's diary [rather] than a celebration of different voices and worldviews" (Šlapkauskaite 2008a: 151) is too strong. The fact that Guilford is unable to offer a full-voiced Lithuanian perspective is, in my opinion, a result of her desire to illustrate the unbridgeable rift between the two parts of the same family. Bitter as it may sound, Guilford shows a pessimistic view on possibilities of mutual understanding of the two parts of the family separated by the Iron Curtain, and, as a result, a just representation of both. Therefore, Guilford's novel definitely can be read in the Self-Other dialectic. But it also becomes an illustration of a painful fissure supplied with inextricable solutions due to the oppressive dominance the members of the same family have been subjected to on a different scale. According to Šlapkauskaite, "[t]hus, Aldona's search for cultural identity in Lithuania marks her attempts to convert the Other into the Same, while at the same time keeping the Other at a safe distance to avoid cultural contaminations" (Šlapkauskaite 2008b: 70).

\section{Conclusions}

Both Underground and The Embrace show the complicated political and social aspects of staying in Lithuania under the Soviet dominance after WWII and emigrating from it. These two novels, by applying the Canadian perspective show the Eastern and Western views on the Second World War and the Cold War periods as well as address the issue of personal choices and their consequences. Both writers admit there are dilemmas on both sides and neither of them can achieve full satisfaction on global and individual levels. It is, however, very significant that stories which stayed underground for years finally surface to be rendered not only in historical sources and documents but also in literature. Both writers are aware of the need to give voice (even impaired at times) to stories coming from ethnic minorities in Canada because by bringing these narratives to the public they will save them from oblivion and silencing. This approach, and simultaneously the authors' similar attitudes to the problem, can be seen in the final sections of $U n$ derground in which the narrator claims that:

[t]he old stories stayed underground in Lithuania, and others like them in Estonia and Latvia, in Poland and Ukraine and other places. As for knowledge of them in the West, they were forgotten in the malls, suburbs and highrises of America. A generation of immigrant children grew up and joined the mainstream, forgetting their sources, the springs and rivulets they had come from, except for a few who were caught in the eddies, turning endlessly, in 
neither the present nor the past, mulling over the unknowability of history and the banality of the present. (301)

Furthermore, both novels fill in the gap in Canadian multicultural literature. Smaro Kamboureli's statement on ethnic anthologies, which by their heterogeneity and plurality often fail to "revise the canon" (2009: 134), calls for a more homogeneous representation of the ex-centric margin. The novels analyzed in this article seem to be the answer to this demand. However, still LithuanianCanadian literature has not been widely recognized in Canada so far. Despite Sileika's acknowledgement in reviews in major Canadian newspapers, both writers, have been overlooked by histories of Canadian literature such as The Cambridge Companion to Canadian Literature (2004) edited by Eva-Marie Kröller, W.H. New's A History of Canadian Literature (2003), and the most recent The Routledge Concise History of Canadian Literature (2011). What is even more, Lithuanian history and Lithuanian-Canadian (or more widely Lithuanian-North American) literature have not yet earned even a short mention in Anna Porter's The Ghosts of Europe. Journeys Through Central Europe's Troubled Past and Uncertain Future (2010) and Eva Hoffman's pioneering work: Exit into History. A Journey Through the New Eastern Europe (1993). In her study of literacy of Lithuanian immigrants to North America, Daiva Markelis (2003) briefly sketches the immigrant biographies of Valeria Kelertas and Irene Guilford, who belong to the same wave of immigration as Antanas Sileika and whose presence is not even referred to. Travestying Iva Polak's questions:

Ultimately, can I as a woman belonging to the white academic mainstream, albeit located in a small country at the edge of Europe, talk about anything removed from my local (and local patriotic) cultural code, my class and gender? Obviously, such restrictions would make me silent and render most scientific research futile. Hence, the alternative has always been to speak "in tongues". This is especially true in today's context of global migrations, cultural synergy and multiculturalism. However, today we should also know that we cannot just speak "in tongues", but learn how to speak "in tongues" (2011: 175).

Sileika's and Guilford's novels respond to these dilemmas straightforwardly. Un/ official histories and personal experiences rooted in Lithuania, a country located "at the edge of Europe", prove viable for multicultural, Canadian literature. By not being only successful stories of heroic deeds and easily formed identities, they offer new stances on what it has meant to be Lithuanian both in the past and today in Lithuania and Canada. Through the fusion of the global with the private, Underground and The Embrace give voice to the previously silenced hi/stories of the perception of the Second World War and the Cold War by LithuanianCanadians. 


\section{Notes}

$1 \quad$ Šlapkauskaite refers to Guilford's The Embrace and Sileika's Buying on Time in her 2008b article but the statement may be a commentary on all of Sileika's works.

2 Sileika also alludes to the ethical problem of the secret war led by the partisans after the Second World War.

\section{References}

Applebaum, Anne [2012] (2013) Iron Curtain. The Crushing of Eastern Europe 1944-1956. New York: Anchor Books.

Bailey Nurse, Donna (2011) 'True patriots in love'. The Globe and Mail. 8 April 2011. http://www. theglobeandmail.com/arts/books-and-media/underground-by-antanas-sileika/article4415819/ (date of access: 2.9.2015).

Danyte, Milda (2003) 'Gender, ethnicity and identity in Canadian ethnic minority fiction: The Lithuanian-Canadian example'. LITERATÜRA 45(4), 74-82.

Danyte, Milda (2007) 'National past / personal past: Recent examples of the historical novel by Umberto Eco and Antanas Sileika'. LITERATÜRA 49(5), 34-41.

Derrida, Jacques (1994) Spectres of Marx. The State of the Debt, the Work of Mourning \& the New International. Tr. Peggy Kamuf. New York and London: Routledge.

Dundzila, Vilius Rudra (2012) Book review 'Antanas Sileika's Underground. A Novel'. Lituanus. Lithuanian Quarterly Journal of Arts and Sciences 58(3) http://www.lituanus. org/2012/12_3_07BR2Sileika.html. Accessed on 2 September 2015.

Gombrich, Ernst Hans [1960] (2000) Art and Illusion. A Study in the Psychology of Pictorial Representation. Princeton and Oxford: Princeton University Press.

Guilford, Irene (1999) The Embrace. Toronto, Buffalo and Lancaster: Guernica.

The Holy Bible. Revised Standard Version (1959) London - Toronto: Thomas Nelson and Sons.

Kamboureli, Smaro (2009) Scandalous Bodies: Diasporic Literature in English Canada. Waterloo: Wilfrid Laurier University Press.

MacLennan, Hugh [1945] (2003) Two Solitudes. Toronto: McClelland and Stewart Ltd.

Marchand, Philip (2011) 'Open book: Underground by Antanas Sileika'. National Post. http:// news.nationalpost.com/afterword/open-book-underground-by-antanas-sileika Accessed on 2 September 2015).

Markelis, Daiva (2003) “"Talking through letters”: Collaborative writing in Early Lithuanian immigrant life'. Written Communication 20(2), 153-169.

Nora, Pierre (1989) 'Between Memory and History: Les Lieux de Memoire'. Representations 26, $7-25$.

Polak, Iva (2011) 'The One about Coyote Going West: Mimesis and ethnics in multicultural literary landscapes of Canada and Australia'. Brno Studies in English 37(1), 173-190.

Pollack, Martin (2014) Skażone krajobrazy. [Kontaminierte Landschaften]. Tr. Karolina Niedenthal. Wołowiec: Wydawnictwo Czarne.

Porter, Anna (2010) The Ghosts of Europe. Journeys Through Central Europe's Troubled Past and Uncertain Future. Vancouver and Toronto: Douglas and McIntyre.

Schama, Simon (1995) Landscape and Memory. New York: Knopf.

Sileika, Antanas (2011) Underground. Toronto: Thomas Allen Publishers.

Šlapkauskaite, Rūta (2008a) 'In the name of the other: Marketing the post-colonial gaze in Irene Guilford's The Embrace'. In: Ní Mhainnín, Máire Áine and Elizabeth Tilley (eds.) Canada: Text and Territory. Newcastle upon Tyne: Cambridge Scholars Publishing, 141-154.

Šlapkauskaite, Rūta (2008b) 'Under the spell of multiculturalism: Irene Guilford's The Embrace and Antanas Sileika's Buying on Time'. LITERATÜRA. 50(4), 63-75. 
Dagmara Drewniak, Ph.D., D. Litt. teaches American and Canadian literature at the Faculty of English, Adam Mickiewicz University, Poznań, Poland. Her research interests include: multiculturalism in literature, images of Poland and Eastern Europe in Canadian literature, literature by immigrants from Poland and Eastern Europe, Jewishness in Canadian literature, and life-writing. She has published essays on Kulyk Keefer, Stachniak, Hoffman, Rushdie, Ondaatje, Appignanesi, and other contemporary writers. She co-edited TransCanadiana Canada and Its Utopia/Canada et ses utopies (2009) and Studia Anglica Posnaniensia (2015). In 2014 she published a book entitled Forgetful Recollections: Images of Central and Eastern Europe in Canadian Literature.

Address: Dr hab. Dagmara Drewniak, Center for Canadian Literature, Faculty of English, Adam Mickiewicz University in Poznań, al. Niepodległości 4, 61-874 Poznań, Poland. [e-mail: dagmarad@wa.amu.edu.pl] 
